\title{
One Germany, Two Worlds of Housework? Examining Employed Single and Partnered Women in the Decade after Unification*
}

\author{
Claudia Geist \\ Carolina Population Center University of North Carolina at Chapel Hill
}

The fall of the "iron curtain" and the end of state socialism in Eastern Europe radically changed Europe in the mid 1990s. Amid the dramatic changes that occurred, Germany stands out as a special case, as the unification process resulted in a rapid adoption of the institutional and economic settings of the Federal Republic of Germany (FRG) in the territory of the German Democratic Republic (GDR). This resulted in fundamental economic and social changes. Prior to unification, the former FRG and GDR had markedly different sociopolitical systems, with a market based capitalist system in the FRG firmly integrated in the western world, and heavily regulated state socialism in the GDR, which was politically and economically aligned with the Soviet Union. As such, Germany is a useful case study that allows the investigation of social processes in one country with uniform legal and policy structures, yet very different institutional legacies and, to this date, substantive regional differences in the levels of female labor force participation. In this study, I examine women's housework in the united Germany.

Housework is an important aspect of gender inequality that affects not only couple relationships, but also individuals' well-being (Cubbins and Vannoy, 2004; Frisco and Williams, 2003). Research on domestic labor has established that although essentially a private activity, housework is shaped by context (Cooke, 2006a; Fuwa and Cohen, 2006; Hank and Jurges, 2007). Individual level mechanisms that influence housework can have varying meaning across contexts (Cooke, 2006a). In an earlier study, I compare the mechanisms influencing the division of labor across liberal, conservative, and social democratic welfare state regimes (based on the categorization by Esping-Anderson [1990]) and find that housework is most unequal in conservative welfare states, with West Germany being the prototypical example for this regime type (Geist, 2005). On the other hand, Batalova and Cohen (2002) find evidence that some mechanisms that predict the division of labor may work differently in Eastern European countries compared to Western Europe. In this paper, the main objective is to examine the determinants of the housework burden of employed women, contrasting East and West German women. Focusing on absolute housework time, rather than the division of labor, I am able to include both women with and without a partner in my analyses, and also examine possible variation in the impact of partnership status on domestic labor performance across regions.

Prior to unification, the differences between the two Germanys encompassed fundamental differences in the economic systems resulting in very different positions of women workers in both regions. However, the regional differences and their consequences were not restricted to the economic realm. Out of the two systems arose ideologies that differed in particular with

\footnotetext{
* This research was supported by the grant 5 T32 HD07168-30, awarded to the Carolina Population Center at The University of North Carolina at Chapel Hill by the Eunice Kennedy Shriver National Institute of Child Health and Human Development. I would like to thank Lynne Prince Cooke, Patricia A. McManus, Eliza K. Pavalko, Brian Powell, and three anonymous reviewers for their thoughtful feedback on earlier versions. Please direct all correspondence to Claudia Geist, Carolina Population Center, University of North Carolina at Chapel Hill, CB\# 8120, 123 West Franklin St., Chapel Hill, NC 27516, or cgeist@unc.edu.
} 
respect to the role ascribed to women in society. In the former West Germany, the prototypical conservative welfare state, women were cast as primary caretakers of the household and there was strong support for the male breadwinner-female homemaker model. This was supported by the tax system, a scarcity of child care facilities and a strong reliance on half-day schooling. In the socialist economy of the GDR, there were no incentives for women to specialize in domestic production. There was a strong system of state run child care facilities, and women's labor market participation was expected, regardless of domestic responsibilities. ${ }^{1}$

One of the keys to explaining gender differences in household labor lies in men's and women's different labor market positions. Fuwa's (2004) findings suggest that in former state socialist countries the effect of women's employment on the domestic division of labor is weaker. In this paper, I focus on the intersection between paid and unpaid work, specifically on how women's employment shapes domestic labor, as the double responsibility for both domestic and paid labor is a major source of stress for women. ${ }^{2}$ This paper further differentiates between full-time and part-time workers, another important distinction that has not been given enough attention in previous treatments of housework. These two groups of workers may have very different self-perceptions regarding their role at home and in the work place, so it should not be assumed that housework is shaped by the same mechanisms for both full-time and part-time workers. The fact that employment is central in shaping domestic labor, combined with the fact that levels of employment continue to differ between East and West Germany suggests that comparing housework in East and West Germany can provide very useful insights.

In sum, studying Germany offers a unique case of providing enough differences to understand the importance of context for shaping housework, while both regions share enough similarities to make a detailed comparison meaningful. This study extends existing comparative work on women's housework in three ways. First, it provides a longitudinal assessment of regional differences in women's housework in Germany, spanning the decade after unification. Second, it compares the housework of both employed single women and those living with a partner, in contrast to existing studies that have focused exclusively on women in relationships. In order to focus on the comparisons among women rather than on the gender division of labor, I rely on absolute housework time instead of measures of housework share. Assessing the housework of unpartnered women is crucial to fully understanding the way housework impacts women, in particular the link between paid and unpaid work and the possible role of family relationships in exacerbating or mitigating regional differences. Third, this paper introduces a novel comparison of housework mechanisms between full-time and part-time workers across contexts, examining whether the salience of paid work shapes the mechanisms of housework allocation. By focusing on employed women regardless of partner status, this study allows a distinction between the impact of time worked for pay, level of labor force participation, and structural context of women's housework.

To this end, I examine unpaid domestic labor time for part-time and full-time employed East and West German women using data from the 1991 through 2001 waves of the German Socioeconomic Panel Data (GSOEP). In the next section, I present conventional explanatory approaches to housework allocation and discuss in more detail the role of context, focusing specifically on the example of Germany.

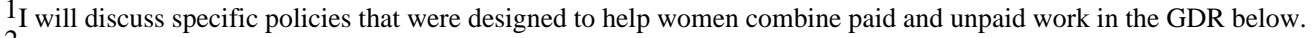

${ }^{2}$ Consequently, I do not include women who do not work for pay. Of course, there are a variety other factors that affect women's housework performance but these are not explicitly considered here.
} 


\section{DETERMINANTS ${ }^{3}$ OF HOUSEWORK: TWO CUSTOMARY APPROACHES}

\section{Housework as "Rational" Arrangement: Time Availability and Resources}

While women have traditionally had the primary responsibility for domestic labor, there is variation in how much housework they actually do. One line of research argues that the allocation of domestic work is based on time availability. Becker (1991) argues that the domestic division of labor reflects rational arrangements between partners who specialize in either domestic or market production, based on evaluations of potential earnings of both partners in the labor market. According to this theory, household labor is not explicitly gendered, but is a function of time and effort spent on paid work. Although the notion of the complete specialization in the form of a breadwinner-homemaker arrangement as "most rational" option has been challenged (Oppenheimer 1997), it is widely accepted that time in the labor market and the subsequent time available for doing housework are key determinants of household labor arrangements.

This approach is intuitively very appealing. The more time is "used up" by employment, the less time is dispensable for housework. ${ }^{4}$ It has been shown that women's labor force participation decreases the number of hours they spend on housework (Baxter, 1992; see also Bianchi, Milkie, Sayer, and Robinson, 2000;Coltrane, 2000; Shelton and John, 1996). Previous research is limited to married and cohabiting women. While Becker's arguments about the division of labor and specialization cannot be generalized to single women, the more general time availability approach can; single women's time available for housework is also limited by the hours they spend on their jobs. For women who are not in the paid labor force, however, the time availability approach cannot explain variation in their housework performance.

Apart from time limits as a major determinant of housework, others have promoted the idea of domestic labor as a reflection of women's bargaining power within a couple. Higher levels of socioeconomic resources are seen as being associated with power in the bargaining process for (less) housework. Consequently, the partner who contributes more money may feel that this contribution excuses him (or, less frequently, her) from housework. If a partner does not earn enough money to support him/herself (and potentially his/her children) independently, the lack of bargaining power can be seen as a form of dependency (Sorensen and McLanahan, 1987). Because of their weak bargaining position, fuelled by their perception that they cannot "afford" to leave the relationship, these "dependent" partners (usually women) may end up with a disproportionately high level of housework. Even if women would theoretically be economically self-sufficient, their current standard of living that relies on the partner's income may be considerably higher than what they could afford on their own (Brines 1994).

While the relative resource/bargaining model only applies to employed women who have a partner, considering available (absolute) resources is important for both singles and coupled women. Higher earnings may translate into the ability to invest in time-saving equipment, and perhaps even more importantly outsourcing of household tasks, such as cooking, cleaning, and laundry. It is important to consider this aspect of financial resources in addition to women's relative resources, for both singles and women with partners. Relative resources may reflect the bargaining power within a couple, but the level of absolute resources may determine how effectively the financial resources may be used in the market place to reduce housework through outsourcing. Women with partners may find it easier to reduce housework time through purchasing services, rather than engaging in bargaining with their partners that may result in

\footnotetext{
${ }^{3}$ Throughout this paper, "determinants of housework" and "mechanisms of housework allocation" are used synonymously.

${ }^{4}$ Of course housework time is also a function of the housework demands of a specific household, i.e., number of household members and the size of the dwelling (see also footnote 5). Since the measure of housework that is used in this paper specifically does not include child care, I discuss parenthood in the section on gendered context of domestic labor.
} 
conflict. ${ }^{5}$ I consider the link between absolute resources and housework as an extension of the more prevalent rational arrangements that applies to all women, not only those with partners.

In my analyses, I will not only replicate established findings regarding the rational explanation of housework, but also extend existing research to singles. Having a partner also means that there is at least the potential for housework sharing. Especially women who have established a certain level of financial autonomy may not increase their housework performance too much once they have a partner. Only through comparing single women to partnered women is it possible to shed light on the role of relationships in shaping women's housework burden, a major factor in gender inequality on a societal level.

In this paper, I focus on employed women who face the double burden of paid and unpaid work. Consequently, I do not include women who do not participate in market work (voluntarily or involuntarily) since they do not have earnings and they have no measurable constraints on their domestic labor.

\section{Housework as Gendered Arrangement}

Time availability and resource approaches are both grounded in rational choice theories of individual behavior. Domestic labor, however, is not entirely based on negotiation processes and rational constraints. If women earned more than their partners, this would not automatically lead to men doing more housework. The assumption of women's primacy in taking on domestic responsibilities is firmly rooted in traditional gender role expectations.

Women's domestic work has been conceptualized as a way of "doing gender." Doing gender is an ongoing process that is expressed in everyday activities. Domestic production is a site where men and women can live out "wifely and husbandly roles" and create gender differentiation. Accordingly, women may do more housework than men in an active effort to affirm their femininity (West and Zimmerman, 1987). There is evidence that entry into a heterosexual union increases women's time spent on housework while simultaneously reducing men's, thus suggesting that the process of doing gender is more pronounced in traditionally gendered contexts (Gupta, 1999; South and Spitze, 1994). Shelton and John (1993) find that it is not the mere presence of a male partner that increases women's housework, but it is the presence of a husband. Baxter (2005) suggests that the "incompleteness" of cohabitation as an institution allows for more flexible negotiations of domestic roles among partners in these unions, leaving more room for equal sharing and more flexibility in task assignment, resulting usually in lower levels of housework for cohabiting women (Cunningham, 2005).

However, these processes are not easily observed, and it is therefore difficult to directly measure the concept of "doing gender" in quantitative studies. Survey data cannot adequately capture the motivational processes that compel women to use housework as way to reaffirm their femininity and offers only limited insights into gender socialization processes. While the underlying motivations cannot easily be observed, it is still possible to derive empirical expectations from the "doing gender" approach. This set of ideas suggests that especially marriage and motherhood will make traditional role expectations more salient for women. Thus, wives and mothers can be expected to do more housework, as they may want to fulfill the expectations of femininity associated with these statuses. Comparing the housework of single and partnered women enables me to test whether having a partner increases women's

\footnotetext{
${ }^{5}$ This study does not investigate the extent to which more resources are associated with more living space and consequently more demand for housework, in particular in the form of cleaning. Also, this paper does not assess the outsourcing of housework. However, the size of houses, apartments, and yards in Germany is typically much smaller than in the United States, and hiring help such as cleaning personnel and staff for yard work is not only more expensive but also less common.
} 
housework net of other factors, as would be expected by the "doing gender" approach, or whether housework is mainly shaped by women's labor supply. I expect that the presence of children further encourages women to "do gender." Of course, children can also be expected to cause an additional need for housework net of childcare (for example, through increased need for cleaning and doing laundry).

\section{HOUSEWORK IN GERMANY: ONE COUNTRY, TWO CONTEXTS}

The two main theoretical approaches outlined above have been studied in depth, and more recent work has begun to integrate a comparative perspective within housework research (Treas and Drobnic, forthcoming). However, comparative research that seeks to identify the effects of sociopolitical context on individual-level outcomes is often hampered by the difficulty of making meaningful comparisons of individuals across different countries. The German case is perfectly suited for this goal, since there is one current unified set of institutions with two different pasts and, as I argue, two different ideological legacies. Others have taken advantage of this unique case study. Trappe and Sørensen (2006) compare household economics across regions, and others have examined regional differences in work values and attitudes towards women's labor force participation (Adler and Brayfield, 1997; Alwin, Braun, and Scott, 1992).

During their 40-year separation, the two territories recovered, rebuilt, and progressed along notably different trajectories. In the GDR, employment was seen as a mechanism to reduce gender inequality. Nevertheless, women were still assumed to hold the primary responsibility for domestic tasks, based on the notion of women as workers and mothers (Adler, 2002; Rudd, 2000). This portrayal of women as "superwomen" in the socialist ideology was motivated by the regime's goal to efficiently use the available workforce to improve the difficult economic situation of the GDR in the postwar period. As a consequence, women's employment was virtually required in the East during the Socialist regime, resulting in extremely high female labor force participation rates (Adler, 1997; Künzler, Walter, Reichart, and Pfister, 2001; Trappe, 1996), and almost no difference in labor force participation among married and unmarried women.

However, East German women's full-time work in the socialist regime did not result in an adjustment of the expectations towards women's role at home. The GDR ideal for women has been coined a "compatible three role model" (kompatibles Drei-Rollen-Model) by Geissler (2002, p. 391), where women were mothers and homemakers, qualified employees, and political and social activists. The notion of women being active in all aspects of social life did not fully translate into an expanded role for men in the domestic sphere. While the GDR constitution proclaimed gender equality, support for women's employment, and the contribution of both men and women to household and parenting responsibilities, traditional role expectations for men remained largely unchanged. Gender equality in politics and employment were supported by government commissions and a high level of state regulation. In the private sphere, gender equality could not be enforced, but a number of measures were taken to alleviate women's burden.

Geissler (2002) provides an excellent overview over the policy package aimed at alleviating the double or triple burden faced by women in the GDR: State sponsored childcare was widely available. Also, mothers (but not fathers) with multiple children received additional vacation days, as well as a reduction in weekly work hours without losing salary or wages. Similar to West Germany, women received paid time off for a full year after the birth of a child, but prolonged withdrawal from the labor market was not encouraged. Married women and mothers (as well as single fathers) also received one paid "housework day" per month (Geissler, 
2002). These policies provide evidence that married women, regardless of parental status, were seen as facing a higher burden of domestic work than single or cohabiting women.

In West Germany, women were perceived and pressured to be wives and mothers first and foremost. As a consequence, women in this region have had weaker preferences for employment than their East German counterparts (Adler and Brayfield, 1997). Women's employment was suppressed by a combination of part-time school days, a tax system that favored inequality in couples' individual earnings, and the state's support of traditional family structures. Thus, women's earnings were often supplementary, further emphasizing the primacy of their domestic responsibilities.

Because women's positions in society differed more markedly between the two states than was the case for men, the political and economic upheaval following unification was particularly traumatic for women. In addition to the ideological differences and institutional transformation, the transition to a capitalist economy was associated with a deep economic crisis that pushed women out of the labor force. The East German economy suffered a tremendous level of job loss and the labor market position of East German women evolved both fundamentally and permanently. The lack of employment opportunities, together with incentives for women to remain at home, reduced East German women's labor market participation to 74\%. This rate was down from almost universal participation among women of working age in the late 1980s and early 1990s. In West Germany, women's participation rates remained relatively stable (around 61\%) during this time period, (Trappe and Rosenfeld, 2002), which was still significantly lower than in East Germany.

The rational approach to housework allocation is based on the premise that couples' domestic labor depends on labor force investment and rewards. Context may shape men's and women's labor force situation, but it does not necessarily enter the housework allocation process directly. The doing gender approach to housework, on the other hand, posits that partnerships, especially marriage and motherhood, activate women's perceived need to affirm their femininity, with housework being one way to do so. Contextual factors can be seen as yet another factor that may shape the extent to which women feel the need to do gender.

In this paper, I link the customary explanations of housework with regional characteristics and argue that the distinct socio-political legacies of the two Germanys result in differences in housework allocation mechanisms. Both the rational and the gendered models lead to similar expectations regarding regional disparities. East German women are more likely to be in the labor force, and more likely to work full-time. On average, they can be expected to make greater contributions to the household's income and have less time available for domestic labor, partly because the availability of childcare facilities enables them to work longer hours doing paid work. Furthermore, East German women were not encouraged to base their female identity on their domestic labor; their integration into society occurred through both work for pay and work at home (Adler, 2002).

Evidence regarding East German women's housework before unification is limited. We know that in both the FRG and the GDR women took on primary responsibility for housework, but there are indications that women in East Germany had more "help" from their partners, resulting in a more equal division of labor (Cooke, 2004; Künzler, Walter, Reichart, and Pfister, 2001; Rosenfeld, Trappe, and Gornick, 2004). Geissler (2002) provides a summary of a report of the division of labor for a number of housework tasks in both regions covering a time period from 1983 to 1996. This report suggests that while a traditional division of labor is prevalent in both regions of Germany, arrangements have been somewhat less traditional in East Germany. 
Recent evidence of German women's housework is mixed. A number of studies indicate that, in fact, East German women with partners face a lower housework burden than West German women (i.e., Cooke, 2006b; Davis and Greenstein, 2004). However, a recent study by Künzler et al. (2001) suggests that this difference is very small. Moreover, the picture for single women's housework is unclear. Adler (2002) finds that unification had a major impact on the way East and West German women conceptualized their work lives, but evidence suggests that East German women hold on to the dual orientation of combining work and family and show no signs of adopting a male-breadwinner/female-homemaker orientation.

Based on the historical legacy, East German women can be expected to do less housework than their West German counterparts. Although theory suggests that regional differences exist for all subgroups, I explicitly test the role of partnership status by examining single women as well as partnered women.

H1: East German women do less housework than West German women.

\section{FULL-TIME AND PART-TIME EMPLOYMENT: DIFFERENTIAL IMPACT ON HOUSEWORK?}

I argue that it is important to move beyond regional differences in housework and also distinguish between different levels of labor market participation when examining women's domestic labor. Varying levels of labor market involvement may reflect the salience of paid labor compared to domestic responsibilities and family life, independent of region of residence. Alternatively, women's investment in the labor market and their need to reaffirm their femininity through (increased) domestic labor may vary. I present competing hypotheses that are based on different theoretical approaches.

Depending on the relative importance of paid versus unpaid work, job hours and economic resources can have a different impact on women's housework patterns. To the extent that parttime participation is a reflection of prioritizing domestic responsibilities over paid work, I expect that part-time workers' housework is not very elastic to their labor supply. In other words, even if women increase their paid work hours and earnings, they will not reduce their time spent on domestic chores, since these are their main priority. Full-time workers, whose first priority is more likely to be paid work, may only engage in housework to the extent that their jobs allow it, and adjust their domestic labor depending on their paid work hours and earnings power. Hypothesis $\mathrm{H} 2$ represents this "employment priority model":

H2: The tradeoff between paid work and unpaid work is stronger for full-time than for parttime workers.

Although it is possible that the link between paid and unpaid labor is the same in both parts of Germany, there are theoretical reasons to expect differences that have remained unexplored thus far. Taking into account the specific regional context of Germany, two alternative hypotheses can be derived.

In West Germany, women's full-time employment may be perceived as a departure from traditional femininity. From a "doing gender" perspective, West German full-time workers may consequently believe that they have to compensate for their market activities and disregard resources offered by paid work and therefore do not reduce their housework time commensurate to their job hours. They may in fact become the "superwomen" touted by the GDR regime attempting to simultaneously excel at parenthood, domestic responsibility, and employment. Accordingly, the expected reduction in domestic labor expected of these fulltime employed women may never occur, given gendered expectations that a woman's 
femininity lies in her domestic prowess. A "doing gender" hypothesis based on this line of thoughts posits:

H3a: For West German women, the tradeoff between paid work and unpaid work is stronger for part-time than for full-time workers.

Turning to East Germany, Trappe and Rosenfeld (2000) find evidence from the 1980s that East German women's careers were less affected by parenthood than those of West German women. Along similar lines, the domestic division of labor in East Germany was rather decoupled from women's market position as full-time employment was the norm. I take these existing findings and extrapolate a new set of expectations: as a continuation of this legacy, it can be expected that there is little trade-off between work for pay and unpaid domestic work in East Germany. Despite the debate about the extent to which East German women welcomed German unification as an opportunity to embrace a more domestic role, Kolinsky (1998) finds evidence that only eight percent of East German unemployed women consider themselves housewives. Furthermore, although the availability and affordability of childcare dropped compared to preunification levels, child-care is still more readily available to East Germans than to West Germans. Consequently, it can be expected that employment shapes housework to a smaller extent in East Germany than in West Germany. Women's part-time employment in East Germany may be a compromise rather than a preference in employment-seeking given that full-time jobs have become more difficult to find and keep. Hypothesis H3b outlines the expectations from the idea of "stable roles" for East German women:

H3b: In East Germany, the link between paid and unpaid work does not differ between fulltime and part-time workers.

\section{DATA AND METHODS}

To test the hypotheses outlined above, I use the German Socio-Economic Panel (GSOEP), a representative panel study of private households in Germany. Data are collected annually on both the household- and person-level and each household member over the age of 16 is interviewed. Data collection in West Germany has been on-going since 1984, and an East German sample was added in 1990. Each person moving out of an original sample household is followed, and each person moving into a sample household becomes a sample member as well. I restrict my analyses to the years 1991 through 2001, for which full information on both regions is available. The panel is unbalanced, with an average of about 7 years of data per respondent. ${ }^{6}$

I examine time spent on housework for employed ${ }^{7}$ women who are between the ages of 25 and $55,{ }^{8}$ who are either single or have a partner living in their household. Households with three adults or more, such as couples who reside with other adults, and singles who live with other adults who are not their partners are excluded. ${ }^{9}$ While investigating the housework of women who are permanently out of the labor force would be interesting, current theories do not provide a good framework for understanding variation in the time they spend on domestic work. The sample further excludes disabled women and those in the military, and is limited to women with positive earnings and positive number of hours worked for pay.

\footnotetext{
${ }^{6}$ Panels also can contain gaps in years.

${ }^{7}$ This paper is restricted to employed women to focus on regional differences in the role of labor market characteristics in women's housework. Theoretical approaches are best fit to explain the tradeoff between paid and unpaid work, and not very much is known about the determinants of housework time for women who are not in the labor force.

${ }^{8}$ This age range captures the time where women are most active in the labor market.

${ }^{9}$ These women are excluded because existing theoretical approaches do not take into account complex family relationships.
} 


\section{Dependent Variable: Housework Time}

Respondents were asked to indicate how many hours they spend in a typical weekday on housework. ${ }^{10}$ For most years, they were also asked to indicate how many hours they do housework on a typical Sunday. ${ }^{11}$ I construct a measure of average housework per day, based on weekdays and weekends..$^{12}$ This measure avoids the problem of double-reporting pointed out by Lee and Waite (2005) who suggest that reports of housework that are based on specific tasks overestimate housework time as multiple tasks may be completed at the same time. The housework measure used in the present study has been deemed highly replicable (Juster, Ono, and Stafford 2003) and, unlike relative housework measures, can be compared across households and over time as a respondent's household composition changes. Although subjective reports of housework may be biased (e.g. respondents over-report their own housework and underreport their partner's housework), the impact of this bias on the results of this study are minimal, since only women's own absolute housework time is taken into account. Examining time spent on housework rather than individual tasks also circumvents the problem that the predictors of housework operate differently for traditionally feminine, masculine, and gender neutral tasks (Kroska 2004). To facilitate interpretation, housework time is recoded from hours to minutes.

\section{Independent Variables}

I include specific measures for the "rational" mechanism of housework allocation: time availability and resource-based bargaining. While I cannot directly measure gender roles or "doing gender," I include indicators of parenthood and details on partner status.

The time availability aspect of women's work is measured by the number of hours worked for pay per week. ${ }^{13}$ In later parts of the analyses, I distinguish between full-time and part-time employees, using 30 hours per week as a threshold for full-time versus part-time employment.

Resources are measured by two different indicators. I include women's shares of the couple's labor income. Women who do not have a partner are considered to be contributing $100 \%$. I also include a measure of a respondent's absolute earnings. To address the problem of the distinct earnings distributions in the two regions, I create a measure that represents the difference between the natural logarithm of respondents' earnings and the mean earnings in their region of residence. This earnings measure can be interpreted as the percentage difference between individual and mean earnings at the regional level.

To assess the role of gender roles and doing gender, I distinguish between single women, women cohabiting with their partners, and married women. As outlined above, women can be expected to perform gender normative behavior to a greater extent when they are in heterosexual unions, especially marriage. I further distinguish between parents and nonparents, based on the presence of children in the household, as an additional measure of the salience of

\footnotetext{
${ }^{10}$ This measure of housework is not task based; respondents are only asked to not include child care into their housework time. While child care is a demanding task figuring prominently in the lives of families that have children, I choose not to investigate it since this activity is not performed by all women, in particular those without children.

${ }^{11}$ In some years, there is additional information for housework on Saturdays. Approximately every other year, only information on weekdays is available. Since I control for year of survey in multivariate analyses, this does not pose a problem. For figures, only housework on weekdays is used.

12 Additional analyses were performed using only housework on weekdays. While they yield very similar results, I include the available information on weekend housework since it can be assumed that especially women who work full-time may shift housework time from the week into the weekend.

${ }^{13}$ This measure reflects the actual hours worked, rather than the contractually agreed upon hours.
} 
traditional femininity and housework burden. ${ }^{14,15}$ Also included in the multivariate models are indicators for year and a categorical measure of education.

Many of these factors included have been regularly used in the literature, but I advance this strand of research by specifically examining the regional variation in these mechanisms for both singles and women with partners. The key indicator for the socio-political context in which housework occurs is the region where women first entered the sample, distinguishing between the territory of the former GDR and East Berlin on the one hand, and the states of the former FRG and West Berlin on the other hand. I limit my sample to women who still reside in the region of Germany from which they were originally sampled, in order to study the effect of the socio-political legacy.

\section{Analytic Strategy}

I examine summary statistics and compare average housework levels among subgroups over time. I estimate random effects regressions of housework time on selected labor market characteristics, family structure, and controls. Random effects models take advantage of the multiple time points available for respondents, but also include a random component for each respondent, to take unobserved heterogeneity into account. This is particularly important since the data do not include information on individual attitudes. Hausman tests imply that there are no systematic differences between the random and fixed effects models for East Germany, while there may be for the West German sample. Given the research question at hand, however, the random effects model is still preferred because it allows the examination of the effect of stable characteristics, such as region of residence, one of the key interests of this paper. ${ }^{16}$

\section{RESULTS}

The descriptive statistics presented in Table 1 show that the regional differences in employment and earnings are similar to the differences discussed in the literature motivating this study. West German women spend more time on domestic labor than do East German womenapproximately 20 minutes per day, which adds up to nearly 2.5 hours per week. Further group comparisons show that partnered women do significantly more housework than their single counterparts, 153 minutes vs. 115 minutes. Over the course of a week, this translates into about 4.5 additional hours of housework for women with partners. Further multivariate analyses will have to show whether these differences are due to demographic characteristics, differences in labor market behavior, or whether regional context and relationship status have an independent effect on women's housework. ${ }^{17}$

Figure 1 illustrates the regional differences in housework over time. ${ }^{18}$ In all years, East German women do less housework than West German women, which supports the regional difference hypothesis $\mathrm{H} 1$ and prior research on German women's household labor behavior. Contrary to results from earlier comparative studies, however, I do not find evidence for convergence in housework levels between the two regions over the years.

\footnotetext{
${ }^{14}$ For this analyses, I only children that live in the respondent's household, thereby excluding possible children who may not live at home.

15 Additional analyses, not shown here, were performed with a measure of the number of children. The results were substantively identical.

16 In fixed effects models, one can only discern the impact of changes in individual level characteristics on housework time.

${ }^{17}$ Respondents contribute multiple observations over the years and as a result, some respondents will be counted twice in subsequent tables when they are part of multiple subgroups (e.g., when they enter the analyses for singles and women with partners, because they change their status over the years). Each observation is only included once.

${ }^{18}$ Because weekend housework measures are only available about every other year, time trends are shown only for weekday housework. While visually distracting because of the fluctuating patterns, the results for the total housework (average housework across the entire week) are substantively identical.
} 
The multivariate results in Table 2 support the rational approach to housework, as time in paid work and financial resources reduce women's domestic labor. The results also clearly illustrate that housework allocation is a gendered process. Married women and women with children do significantly more housework than single women and non-mothers with otherwise identical characteristics. The results from the pooled analysis provide support for hypothesis H1: even after controlling for individual, household, and labor market characteristics, East German women spend less time on housework than their West German counterparts.

In a next step, I model housework separately for women in East and West Germany, subjecting hypothesis $\mathrm{H} 1$ to a more stringent test. Table 2 illustrates that the determinants of housework are remarkably similar across regions. The only two clear regional differences are in the impact of parenthood and absolute resources. Motherhood increases housework to a greater extent in West Germany than in the East. This highlights that the meaning of children varies regionally. In contrast, East German women's earnings reduce their housework to a smaller extent than in West Germany. The results from these models do not support hypothesis 1: although East German women on average still do less housework than West German women do, this difference is no longer statistically significant once the mechanisms predicting housework levels are allowed to vary regionally.

I next examine the East-West disparity in housework separately for singles and partnered women. Figure 2, Panel A suggests that, on average, women with partners do more housework than singles in both regions across all years. What is remarkable, however, is that there are no differences in the housework time of East and West German singles. The East-West differences in housework seem to stem from the fact that West German women with partners do significantly more housework than their East German counterparts. This indicates that regional differences in women's housework behavior may be shaped by context-specific family institutions, rather than by a direct impact of the policy context on women's individual ideology, preferences, and subsequent behavior.

The separate multivariate analyses for women with and without partners are presented in Table 3. Results for women with partners are not substantially changed from prior models for all women combined. Motherhood is associated with less additional housework in East Germany than in the West, and East German women's earnings are not as effective in reducing their housework time as they are in West Germany. While the results show some limited differences in the mechanisms of housework allocation, there are no overall East-West differences for women with partners after controls for individual characteristics are included, failing to support hypothesis $\mathrm{H} 1$.

For single women, however, there are no significant regional differences in overall housework levels or in the determinants of housework, confirming the descriptive results from Figure 2, Panel A. This suggests that the effect of context is intimately linked to living with a partner, and singles' housework is unaffected by the regional differences.

Panel B of Figure 2 shows differences between full-time and part-time workers and suggests that the regional differences in housework may be restricted to part-time workers as there are very limited regional differences in the housework time of full-time workers. Additional comparisons of average housework time and average number of hours worked per week for East and West German full- and part-time workers are presented in Appendix 1.

To further test the employment priority model (H2), the "doing gender" hypothesis (H3a), and the "stable roles" hypotheses (H3b), I estimate the overall differences between full-time and part-time workers for both regions combined and for each region separately for women with partners. The estimates for full-time and part-time workers shown in Table 4 suggest that for part-time workers, children are associated with more additional work. Part-time workers' 
housework time is also more affected by their resources; full-time workers may not be as effective as part-time workers in translating their earnings power into less housework. Accordingly, the estimates provide no support for the employment priority hypothesis $\mathrm{H} 2$, which suggested that the effect of paid work on housework should be stronger among full-time employees. The results further indicate that the overall gaps in housework time between fulltime and part-time workers are explained by individual characteristics and the differences in housework allocation mechanisms.

A further breakdown by region is presented in Table 5. Unlike in previous models, time, resources, and household composition do not shape women's housework time for all subgroups among women who have partners. The differences between full-time and part-time workers in housework determinants reported earlier in Table 4 seem to be driven by regional characteristics. The difference between full-time and part-time workers in the role of motherhood for housework is an East German phenomenon, since in West Germany there are no differences by labor force participation. However, the differences between full-time and part-time employees in the impact of paid work on unpaid housework are limited to West Germany. There, part-time workers reduce their housework to a greater extent than those working full-time as paid work hours and relative earnings increase. In East Germany, on the other hand, there are no significant differences by level of employment. ${ }^{19}$ These results provide support for hypotheses $\mathrm{H} 3 \mathrm{a}$ and $\mathrm{H} 3 \mathrm{~b}$, and thus further contradict hypothesis $\mathrm{H} 2$. In supplemental analyses (details not shown), I examine the regional differences across the two employment groups, and I find that net of individual characteristics there are no overall regional differences in the housework time for part-time and full-time workers, respectively. However, the presence of children and women's earnings operate differently in East and West Germany for full-time workers (as indicated by the shading in Table 5); West German women's individual earnings are much more closely linked to housework hours than is the case among East German women. ${ }^{20}$ I fail to find similar regional differences among part-time workers.

\section{SUMMARY AND CONCLUSIONS}

This study compares East and West German women in the decade after the dramatic political changes of German unification. I expand existing studies of housework in Germany by examining women with partners as well as singles; I further distinguish between full-time and part-time workers. These comparisons allow me to identify the extent to which ideological legacies and the historic differences in women's labor market status shape the impact of current employment or partner status on housework performance. This study also investigates women's housework burden in East and West Germany and examines how paid work shapes their domestic labor using data from the German Socio-Economic Panel.

I find that, overall, East German women do less housework than West German women, and married women do significantly more housework than single women with otherwise identical characteristics. The East-West disparity in housework exists only among women with partners: I find a notable absence of differences in the housework time and housework allocation mechanisms between East and West German singles.

East German women with partners have to earn significantly more money than their West German counterparts to reduce their housework by a similar amount, as they are not as effective in translating their earnings into less housework. Furthermore, I find evidence that the impact

\footnotetext{
${ }^{19}$ In supplemental analyses (not shown here) I examine differences between full-time and part-time workers across regions for singles. I find that among West German singles, the effect of paid work hours on housework time differs between full-time part-time workers in ways similar to women with partners: part-time workers experience a greater reduction in housework time as they increase work hours compared to those working full-time.

${ }^{20}$ Among single women, this is only the case for part-time workers, but not among those working full-time.
} 
of motherhood on housework varies between the two parts of Germany. The smaller housework burden imposed by children in East Germany may be due to the (still) superior child care infrastructure which may result in less additional child related housework.

In the comparison of full-time and part-time workers, I find that the effect of paid work on housework is stronger among part-time than among full-time employees. Part-time workers' housework time is more affected by their economic resources, indicating that full-time workers are not as effective as part-time workers in translating their earnings power in less housework. In examining the intersection between the East-West disparity and the full-time/part-time divide in housework, I find that the differences in the role of paid work between full-time and part-time employees are limited to West Germany. There, part-time workers reduce their housework more strongly as their paid work hours and earnings increase, while in East Germany there are no significant differences by level of employment.

The results of this study have a number of important implications for understanding the intersection of socio-cultural context, family, and work. The lack of regional differences among singles suggests that East-West disparities in women's housework behavior are tied to family institutions. While policy context may shape women's ideology towards family and work universally, the effect seems to be tied to being in a relationship.

West German women with partners who work full-time may perform a disproportionate share of housework to overcompensate for their non-traditional levels of labor market activity. Another interpretation is that in contexts where working full-time has a long-standing tradition, it may not be perceived as defeminizing. When women have paid work as their primary activity, their earnings may become an integral part of the household economy and can only be partially used to reduce their housework burden. The stronger impact of earnings on reducing domestic labor time for women working part-time may mean that their earnings are a bonus to the overall household income, available to be spent in more flexible ways.

This interpretation needs to be cautionary, since it is based on the assumption that women's labor force participation is a reflection of their preferences. What is considered the typical level of women's employment differs markedly between East and West Germany. The legacy of GDR state socialism as well as the FRG breadwinner model is reflected in the current participation patterns. Full-time employment is still more likely in the East, while in the West part-time employment continues to be dominant among women; there, a deviation from the predominant participation patterns may frequently be a reflection of economic necessities. East German women's part-time work may be a result of a constrained labor market with a lack of available full-time jobs, which may explain the lack of differences in the determinants of housework between part-time and full-time workers. In contrast, in West Germany the "choice" to work full-time may come at the price of overcompensating with housework performance.

My paper offers a complex answer to those who seek to identify mechanisms that reduce women's (double) burden of paid work and housework. The absence of systematic differences between East and West German singles suggests that the role of context operates through family institutions, partnership and parenthood. Moreover, a discount effect may devalue women's paid work where it is taken for granted, as has traditionally been the case in East Germany. This suggests a potential dilemma in looking at the future of women's housework burden and gender stratification in general. A reduction of women's time spent on domestic labor is important both for reducing gender inequality in the home as well as to enable them to effectively pursue their paid work careers. But the increased integration of women in the labor force alone may not be able to achieve this goal. The underlying value system of task allocation within couples and families will have to be addressed as well. 


\section{References}

Adler MA. Social change and declines in marriage and fertility in Eastern Germany. Journal of Marriage and the Family 1997;59:37-49.

Adler MA. German unification as a turning point in East German women's life course: biographical changes in work and family roles. Sex Roles 2002;47:83-98.

Adler MA, Brayfield A. Women's work values in unified Germany - Regional differences as remnants of the past. Work and Occupations 1997;24:245-266.

Alwin DF, Braun M, Scott J. The separation of work and the family: attitudes towards women's labourforce participation in Germany, Great Britain, and the United States. European Sociological Review 1992;8:13-37.

Batalova JA, Cohen PN. Premarital Cohabitation and Housework: Couples in Cross-National Perspective. Journal of Marriage and Family 2002;64:743-755.

Baxter J. Power attitudes and time: the domestic division of labour. Journal of Comparative Family Studies 1992;23:165-182.

Baxter J. To marry or not to marry: marital status and the household division of labor. Journal of Family Issues 2005;26:300-321.

Becker, GS. A Treatise on the Family (Enlarged Edition). Cambridge, MA: Harvard U Press; 1991.

Bianchi SM, Milkie MA, Sayer LC, Robinson JP. Is anyone doing the housework? Trends in the gender division of household labor. Social Forces 2000;79:191-228.

Brines J. Economic dependency, gender, and the division of labor at home. American Journal of Sociology 1994;100:652-688.

Coltrane S. Research on household labor: modeling and measuring the social embeddedness of routine family work. Journal of Marriage and the Family 2000;62:1208-1233.

Cooke LP. The gendered division of labor and family outcomes in Germany. Journal of Marriage and Family 2004;66:1246-1259.

Cooke LP. "Doing" gender in context: household bargaining and risk of divorce in Germany and the United States. American Journal of Sociology 2006a;112:442-72.

Cooke LP. Policy, preferences, and patriarchy: the division of domestic labor in East Germany, West Germany, and the United States. Social Politics: International Studies in Gender, State \& Society 2006b;13:117-143.

Cubbins LA, Vannoy D. Division of household labor as a source of contention for married and cohabiting couples in metropolitan Moscow. Journal of Family Issues 2004;25:182-215.

Cunningham M. Gender in cohabitation and marriage: the influence of gender ideology on housework allocation over the life course. Journal of Family Issues 2005;26:1037-1061.

Davis SN, Greenstein TN. Cross-national variations in the division of household labor. Journal of Marriage and Family 2004;66:1260-1271.

Esping-Andersen, G. Three Worlds of Welfare Capitalism. London: Polity Press; 1990.

Frisco ML, Williams K. Perceived housework equity, marital happiness, and divorce in dual-earner households. Journal of Family Issues 2003;24:51-73.

Fuwa M. Macro-level gender inequality and the division of household labor in 22 countries. American Sociological Review 2004;69:751-767.

Fuwa M, Cohen PN. Housework and social policy. Social Science Research 2006;36:512-530.

Geissler, R. Die Sozialstruktur Deutschlands. Wiesbaden: Westdeutscher Verlag; 2002.

Geist $\mathrm{C}$. The welfare state and the home: regime differences in the domestic division of labour. European Sociological Review 2005;21:23-41.

Gupta S. The Effects of Transitions in Marital Status on Men's Performance of Housework. Journal of Marriage and the Family 1999;61:700-711.

Hank K, Jurges H. Gender and the division of household labor in older couples: a European perspective. Journal of Family Issues 2007;28:399-421.

Juster FT, Ono H, Stafford FP. An assessment of alternative measures of time use. Sociological Methodology 2003;33:19-54. 
Kolinsky, E. Recasting biographies: women and the family. In: Kolinsky, E., editor. Social Transformation and the Family in Post-Communist Germany. New York: St. Martin's Press; 1998. p. 118-140.

Kroska A. Divisions of domestic work: revising and expanding the theoretical explanations. Journal of Family Issues 2004;25:900-932.

Künzler, J.; Walter, W.; Reichart, E.; Pfister, G. Gender Division of Labor in Unified Germany. Tilburg University Press; Tilburg: 2001.

Lee Y, Waite LJ. Husbands' and wives' time spent on housework: A comparison of measures. Journal of Marriage and Family 2005;67:328-336.

Oppenheimer VK. Women's employment and the gain to marriage: the specialization and trading model. Annual Review of Sociology 1997;23:431-453.

Rosenfeld RA, Trappe H, Gornick JC. Gender and work in Germany: before and after reunification. Annual Review of Sociology 2004;30:103-124.

Rudd E. Reconceptualizing gender in postsocialist transformation. Gender \& Society 2000;14:517-539.

Shelton BA, John D. The division of household labor. Annual Review of Sociology 1996;22:299-322.

Shelton BA, John D. Does marital status make a difference? Housework among married and cohabiting men and women. Journal of Family Issues 1993;14:401-420.

Sorensen A, McLanahan S. Married women's economic dependency. American Journal of Sociology 1987;93:659-687.

South SA, Spitze G. Housework in marital and nonmarital households. American Sociological Review 1994;59:327-347.

Trappe H. Work and family in women's lives in the German Democratic Republic. Work and Occupations 1996;23:354-377.

Trappe H, Rosenfeld RA. How do children matter? A comparison of gender earnings inequality for young adults in the former East Germany and the former West Germany. Journal of Marriage and the Family 2000;62:489-507.

Trappe H, Rosenfeld RA. Occupational sex segregation in state socialist and market economies: levels, patterns, and change in East and West Germany, 1980s and 1998. Research in Social Stratification and Mobility 2002;19:231-267.

Trappe H, Sørensen A. Economic relations between women and their partners: an East and West German comparison after reunification. Feminist Economics 2006;12:643-665.

Treas, J.; Drobnic, S., editors. Women, Men, and Housework in Cross-National Perspective. Stanford: Stanford University Press; Dividing the Domestic. forthcoming

West C, Zimmerman DH. Doing gender. Gender \& Society 1987;1:125-151. 


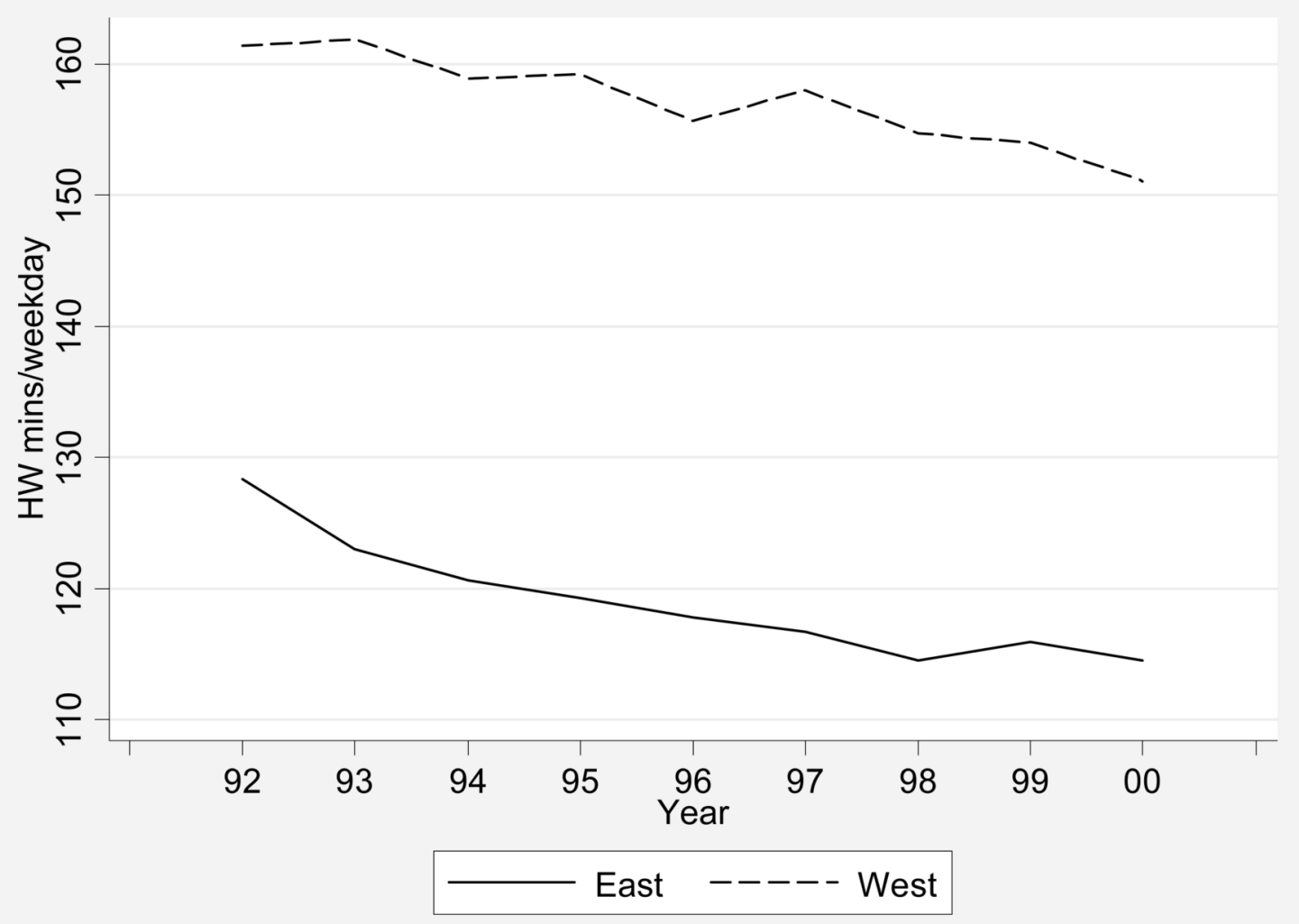

Figure 1.

Average Housework Time, by Region

Note: Figure is based on 3 year moving averages of average housework on weekdays. 

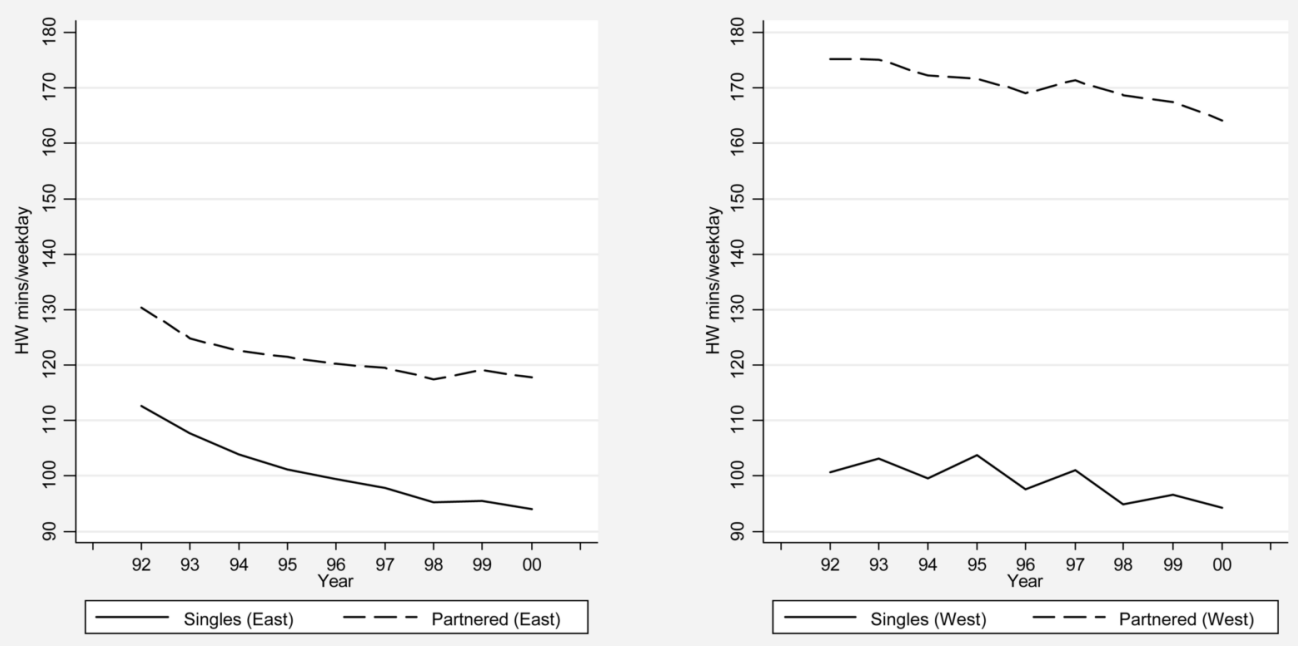

Panel B: By Region and Employment Level (Partnered Women only)
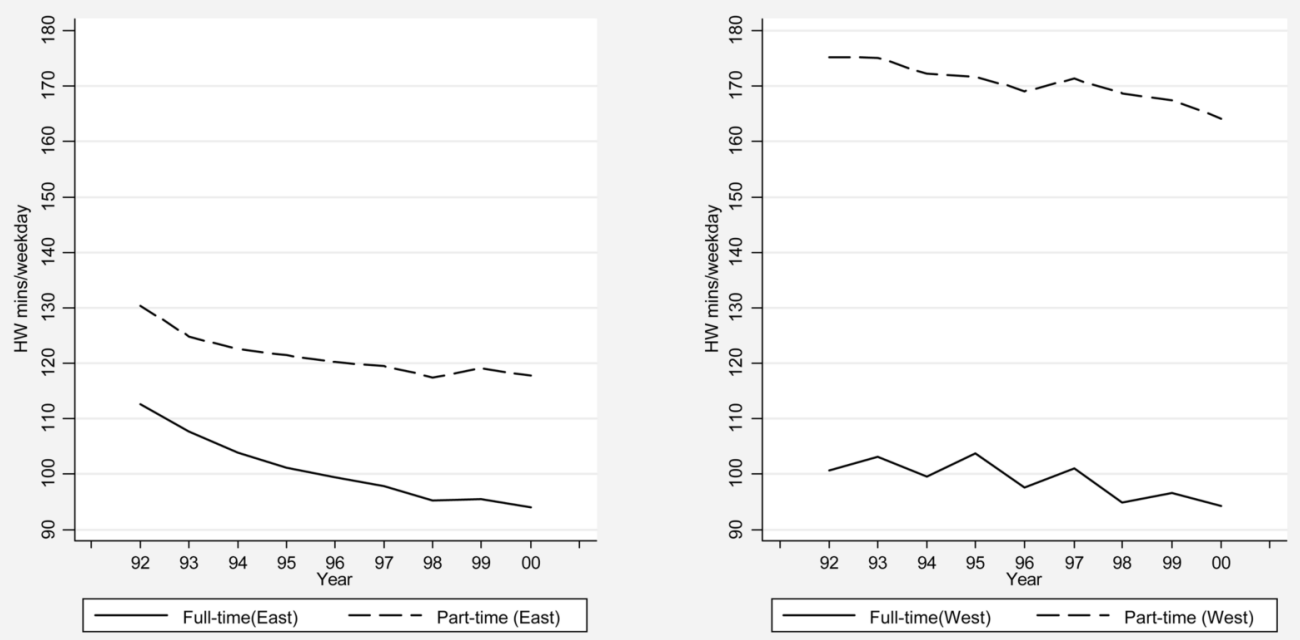

Figure 2.

Housework Time by Subgroups

Note: Figures are based on 3 year moving averages of average housework on weekdays. 


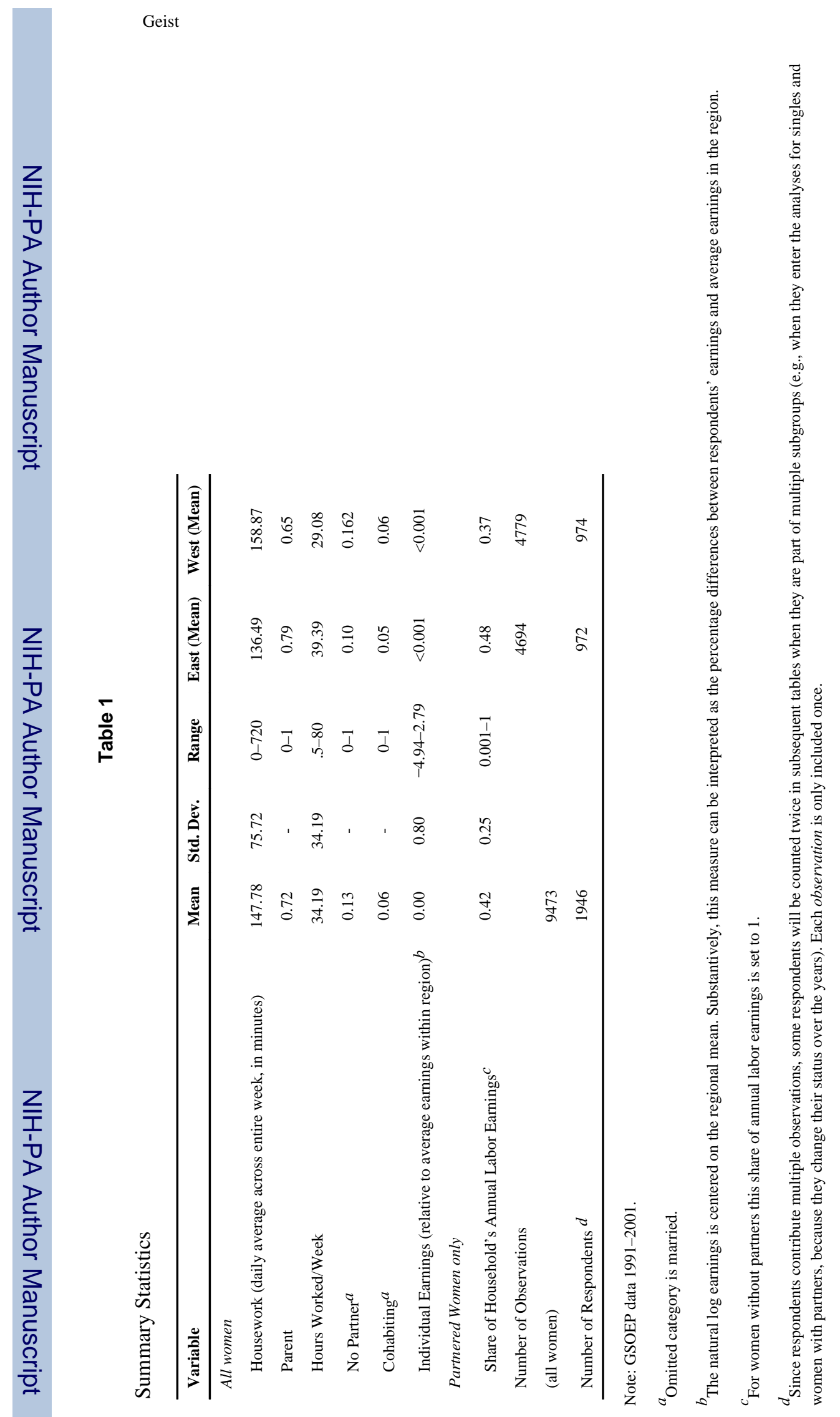

Page 18 
Table 2

Housework Determinants

\begin{tabular}{lccc}
\hline & \multicolumn{3}{c}{ Daily Housework Time } \\
& All & East & West \\
\hline Parent & $23.634(9.78)^{* *}$ & $15.178(4.88)^{* * \dagger}$ & $27.991(7.47)^{* *}$ \\
Cohabiting & $2.184(0.49)$ & $1.562(0.28)$ & $2.548(0.38)$ \\
Married & $12.918(3.93)^{* *}$ & $8.083(1.96)^{*}$ & $13.980(2.77)^{* *}$ \\
Hours worked per Week & $-1.090(14.00)^{* *}$ & $-0.959(9.64)^{* *}$ & $-1.112(9.26)^{* *}$ \\
Individual Earnings & $-13.623(10.21)^{* *}$ & $-7.322(4.03)^{* * \dagger}$ & $-16.662(8.44)^{* *}$ \\
Share of Annual Household Earnings & $-20.916(5.39)^{* *}$ & $-13.683(2.70)^{* *}$ & $-27.869(4.81)^{* *}$ \\
East & $-10.186(3.76)^{* *}$ & - & - \\
Constant & $198.619(12.19)^{* *}$ & $162.171(4.02)^{* *}$ & $202.430(10.29)^{* *}$ \\
Observations & 9473 & 4694 & 4779 \\
Number of Respondents & 1946 & 972 & 974 \\
\hline
\end{tabular}

Note: Estimates are based on random effects regression. Estimated models include controls for educational categories and survey years (not shown here), numbers in parentheses are $t$ values based on robust standard errors. Random effects estimators for the pooled were compared to a fixed effects specification, but random effects models are preferred based on Hausman tests.

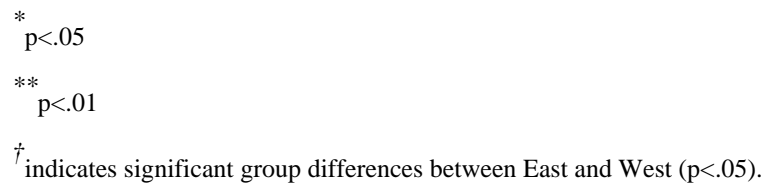


Table 3

Housework Determinants by Region and Partner Status

\begin{tabular}{|c|c|c|c|c|}
\hline & \multicolumn{2}{|c|}{ Daily Housework Time Women with Partners } & \multicolumn{2}{|c|}{ Daily Housework Time Women without Partners } \\
\hline & East & West & East & West \\
\hline Parent & $13.851(4.05)^{* * \dagger}$ & $30.061(7.07)^{* *}$ & $26.041(3.72)^{* *}$ & $22.673(3.49)^{* *}$ \\
\hline Cohabiting & $-7.609(1.46)$ & $-9.525(1.51)$ & N/A & N/A \\
\hline Hours worked per Week & $-0.990(9.36)^{* *}$ & $-1.190(8.96)^{* *}$ & $-0.795(2.77)^{* *}$ & $-0.590(2.16)^{*}$ \\
\hline Individual Earnings & $-7.683(3.93)^{* * \dagger}$ & $-17.800(8.23)^{* *}$ & $-10.889(2.24)^{*}$ & $-9.852(2.12)^{*}$ \\
\hline Share of Annual Household Earnings & $-13.046(2.47)^{*}$ & $-25.100(4.08)^{* *}$ & N/A & N/A \\
\hline Constant & $186.292(4.49)^{* *}$ & $215.297(11.10)^{* *}$ & $153.057(7.55)^{* *}$ & $117.784(6.22)^{* *}$ \\
\hline Observations $^{\mathrm{a}}$ & 4218 & 4004 & 476 & 775 \\
\hline Number of Respondents & 883 & 840 & 151 & 195 \\
\hline
\end{tabular}

Note: Estimates are based on random effects regressions. Estimated models include controls for educational categories and survey years (not shown here), numbers in parentheses are t values based on robust standard errors.

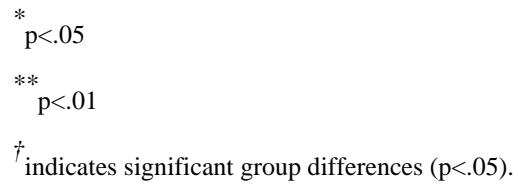


Table 4

Housework Determinants by Labor Market Status

\begin{tabular}{lcc}
\hline & \multicolumn{2}{c}{ Daily Housework Time } \\
\hline & $34.592(6.31)^{* * \dagger}$ & $19.283(7.73)^{* *}$ \\
\hline Parent & $-4.130(0.37)$ & $-8.293(2.31)^{*}$ \\
Cohabiting & $-1.635(5.98)^{* * \dagger}$ & $-0.594(5.04)^{* *}$ \\
Hours worked per Week & $-13.808(5.55)^{* *}$ & $-8.431(5.25)^{* *}$ \\
Individual Earnings & $-39.747(5.88)^{* * \dagger}$ & $-21.820(6.19)^{* *}$ \\
Share of Annual Household Earnings & $-10.942(1.95)$ & $0.491(0.17)$ \\
East & $241.239(10.13)^{* *}$ & $163.197(6.18)^{* *}$ \\
Constant & 2893 & 6580 \\
Observations & 841 & 1517 \\
Number of Respondents & & \\
\hline
\end{tabular}

Note: Estimates are based on random effects regressions. Estimated models include controls for educational categories and survey years (not shown here), numbers in parentheses are t values based on robust standard errors.

$\mathrm{p}<.05$

*** $\mathrm{p}<.01$

${ }^{\dagger}$ indicates significant group differences $(\mathrm{p}<.05)$. 
